\title{
Inhibitory Effect of Atrial Natriuretic Peptide on Accelerated Endothelin Secretion from Cultured Human Endothelial Cells
}

\author{
Hiroaki Yoshida, Motoyuki Nakamura, Shinji Makita, and Katsuhiko Hiramori \\ The Second Department of Internal Medicine, Iwate Medical University, Morioka, Japan.
}

\begin{abstract}
This study investigated the effect of atrial natriuretic peptide (ANP) on endothelin (ET) secretion from cultured human endothelial cells. Confluent umbilical venous endothelial cells were incubated with experimental agents in multi-well plates, and the level of immunoreactive ET in the medium was measured by radioimmunoassay. There was no significant effect of ANP $\left(10^{-8}, 10^{-7}\right.$ and $\left.10^{-6} \mathrm{M}\right)$ on ET secretion after a 3- or 6-hour incubation. However, with 24-hour incubation, ANP significantly inhibited ET secretion from cultured human endothelial cells (control, $139.0 \pm 7.2 \mathrm{fmol} /$ well ; $10^{-8} \mathrm{M}, 89.4 \pm 4.7 \mathrm{fmol} / \mathrm{well} ; 10^{-7}$ $\mathrm{M}, 79.4 \pm 8.2 \mathrm{fmol} / \mathrm{well} ; 1^{-6} \mathrm{M}, 71.0 \pm 10.1 \mathrm{fmol} /$ well, $\left.\mathrm{P}<0.01\right)$. Furthermore, the addition of 8-bromo-cyclic GMP to the medium inhibited ET secretion (control, 147.2 $\pm 2.9 \mathrm{fmol} /$ well ; $10^{-5} \mathrm{M}, 140.9 \pm 2.3 \mathrm{fmol} /$ well ; $10^{-4} \mathrm{M}, 143.0 \pm 1.0 \mathrm{fmol} /$ well ; $10^{-3} \mathrm{M}, 96.6 \pm 6.3 \mathrm{fmol} /$ well, $P<0.01$ ). These findings demonstrate that ANP inhibits accelerated ET secretion from cultured human endothelial cells, probably due to augmentation of intracellular cyclic GMP levels by ANP-activated guanylate cyclase. J Atheroscler Thromb, 1994 ; 1 : 76-79.
\end{abstract}

Key words : Cyclic GMP, Cell culture, Endothelin, Atrial natriuretic peptide

\begin{abstract}
Atrial natriuretic peptide (ANP) is a polypeptide which regulates body fluid volume and sodium balance through its potent natriuretic properties (1). Furthermore, ANP is known to relax vascular smooth muscle cells in the absence of endothelium (2). It has therefore been speculated that endothelial cells do not have an important role to play in the effect of ANP on vasodilation. However, recent observations have demonstrated that ANP receptors are present on endothelial cells (3), and that ANP increases cyclic GMP levels in these cells (4). These observations suggest that ANP influences on endothelial function. However, this effect has received very little scrutiny, especially concerning the release or synthesis of endothelium-derived vasoactive substances.

Endothelin (ET) is a recently discovered 21-amino-acid sequenced polypeptide which is secreted from vascular endothelial cells (5). This peptide has been reported to have potent vasoconstrictive and proliferative properties

Address for correspondence: Hiroaki Yoshida, MD, The Second Department of Internal Medicine, Iwate Medical University, Uchimaru 19-1, Morioka 020, Japan.

Received September 20, 1993.

Accepted for publication January 24, 1994
\end{abstract}

on vascular smooth muscle cells $(6,7)$. Systemic administration of synthetic ET has induced significant biological effects such as an increase of blood pressure, a reduction in cardiac output, and antinatriuresis in humans and animals $(8,9)$. Furthermore, elevated plasma ET levels have been reported in patients with essential hypertension (10), atherosclerosis (11) and congestive heart failure (12). These findings suggest that ET may contribute to the pathogenesis of these conditions (13). However, the mechanism of ET secretion from vascular endothelial cells is unclear. This study was carried out to clarify the effects of ANP on ET secretion from cultured human vascular endothelial cells.

\section{Materials and Methods}

\section{Materials}

ANP was purchased from the Peptide Institute (Osaka, Japan), and 8-bromo-cyclic GMP was obtained from Sigma Chemical Co. (St Louis, MO). Modified MCDB 131 (EBM or EGM-UV, Kurabou, Osaka, Japan) was used as the culture medium. 


\section{Cell culture and experiments}

Endothelial cells were obtained from human umbilical cord veins according to the modified method previously described by Jaffe et al. (14). These were subcultured with calf-serum containing medium (EGM-UV) at $37^{\circ} \mathrm{C}$ under $5 \% \mathrm{CO}_{2} / 95 \%$ air. The cultured cells were identified as endothelial cells by the typical cobble-stone morphology and immunoenzymatic staining of factor VIII, which are characteristic features of vascular endothelial cells. The cultured cells were detached from the culture flasks by trypsin, and were seeded at a concentration of $2 \times 10^{4}$ cells $/ \mathrm{ml}$ onto 24 multi-well plates. Confluent cells were obtained $5 \sim 7$ days after subseeding, at which point the incubation medium was replaced with $0.5 \mathrm{ml}$ of fresh serum-free medium (EBM) and preincubated for 1 hour. After preincubation, the medium was exchanged for $1.0 \mathrm{ml}$ of serum-free medium (EBM) with or without the experimental agents added, and this was incubated at $37^{\circ} \mathrm{C}$. At the end of incubation, the medium was removed from the wells and stored immediately at $-70^{\circ} \mathrm{C}$ until assayed.

\section{Assay of ET}

The concentration of ET in the medium was measured by direct radioimmunoassay using a specific ${ }^{125}$-ET assay system (RPA-555, Amersham, Buckinghamshire, UK). This antibody has a cross-reactivity of $100 \%$ with ET-1, $144 \%$ with ET-2, $52 \%$ with ET-3 and $0.4 \%$ with big ET-1. The sensitivity of ET concentration was $0.5 \mathrm{fmol} /$ tube.

\section{Statistics}

The data were expressed as mean \pm SEM, and were evaluated by one-way analysis of variance. A value of $\mathrm{p}<0.05$ was considered statistically significant.

\section{Results}

\section{Basal ET accumulation in control wells}

The accumulation of ET in the medium increased in a time-dependent manner from 3 to 24 hours after the commencement of incubation. The concentration of ET in the control wells was $3.1 \pm 3.1 \mathrm{fmol} /$ well for $3 \mathrm{hrs}, 16.3 \pm$ $5.1 \mathrm{fmol} /$ well for $6 \mathrm{hrs}, 58.7 \pm 3.2 \mathrm{fmol} /$ well for $12 \mathrm{hrs}$, and $139.0 \pm 7.2 \mathrm{fmol} /$ well for $24 \mathrm{hrs}$ (Fig. 1).

\section{Effects of ANP on ET secretion}

ANP $\left(10^{-8}, 10^{-7}\right.$ and $\left.10^{-6} \mathrm{M}\right)$ significantly inhibited ET secretion from cultured human endothelial cells over a 24-hour incubation (control, $139.0 \pm 7.2 \mathrm{fmol} /$ well ; $10^{-8} \mathrm{M}$, $89.4 \pm 4.7 \mathrm{fmol} /$ well ; $10^{-7} \mathrm{M}, 79.4 \pm 8.2 \mathrm{fmol} /$ well ; $10^{-6}$ $\mathrm{M}, 71.0 \pm 10.1 \mathrm{f} \mathrm{mol} /$ well, $\mathrm{P}<0.01 ; \mathrm{n}=6$, Fig. 1). However, no significant effect of ANP on ET secretion was noted in the experiments employing a shorter incubation period of 3 or 6 hours.

\section{Effects of 8-bromo-cyclic GMP on ET secretion}

The addition of 8-bromo-cyclic GMP $\left(10^{-5}, 10^{-4}\right.$ and $10^{-3}$

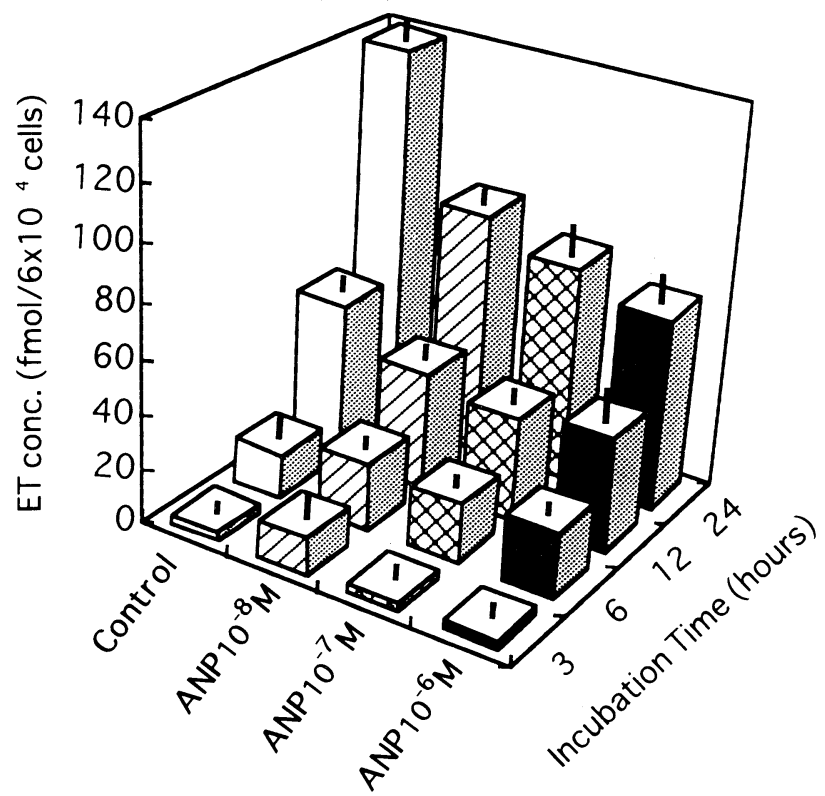

Fig. 1. Time course of the effects of various concentrations of atrial natriuretic peptide (ANP) on endothelin (ET) secretion from cultured human endothelial cells. The accumulation of ET in the control well increased in a time-dependent manner. The ANP-induced inhibitory action of ET secretion was apparent in the 12- and 24-hour experiments (at $12 \mathrm{hrs}, \mathrm{p}<0.05$; at $24 \mathrm{hrs}, \mathrm{p}<$ $0.01)$, while any effect after 3 or 6 hours was obscure. open bar, control ; hatched bar, ANP $10^{-8} \mathrm{M}$; crosshatched bar, ANP $10^{-7} \mathrm{M}$; black bar, ANP $10^{-6} \mathrm{M}$. Data was expressed as mean \pm SEM.

M) to the medium used in the 24-hour incubation resulted in inhibition of ET secretion only at the $10^{-3} \mathrm{M}$ concentration (control, $147.2 \pm 2.9 \mathrm{fmol} /$ well ; $10^{-5} \mathrm{M}, 140.9 \pm 2.3$ $\mathrm{fmol} /$ well ; $10^{-4} \mathrm{M}, 143.0 \pm 1.0 \mathrm{fmol} /$ well ; $10^{-3} \mathrm{M}, 96.6 \pm$ $6.3 \mathrm{fmol} /$ well, $\mathrm{P}<0.01 ; \mathrm{n}=4$, Fig. 2).

\section{Discussion}

This study demonstrates that ANP inhibits ET secretion in a concentration-dependent like manner from cultured human endothelial cells. This effect was clearly evident after 24-hours incubation, but was obscure after 3- or 6hours incubation.

There is no previous report investigating the time course of ANP's effects on ET secretion in the manner of the present study. Kohno et al. (15) examined the effect of ANP on ET secretion over a 4-hour incubation period using cultured human endothelial cells, and reported that although ANP had no effect on ET secretion under basal conditions, secretion was inhibited when ET secretion was stimulated by thrombin.

In the present experiment, the mean value of ET secretion in the control wells during the first 3 hours was 3.1 $\mathrm{fmol} /$ well. If it is assumed that ET was secreted at a constant rate during the entire 24 -hour period, the total 


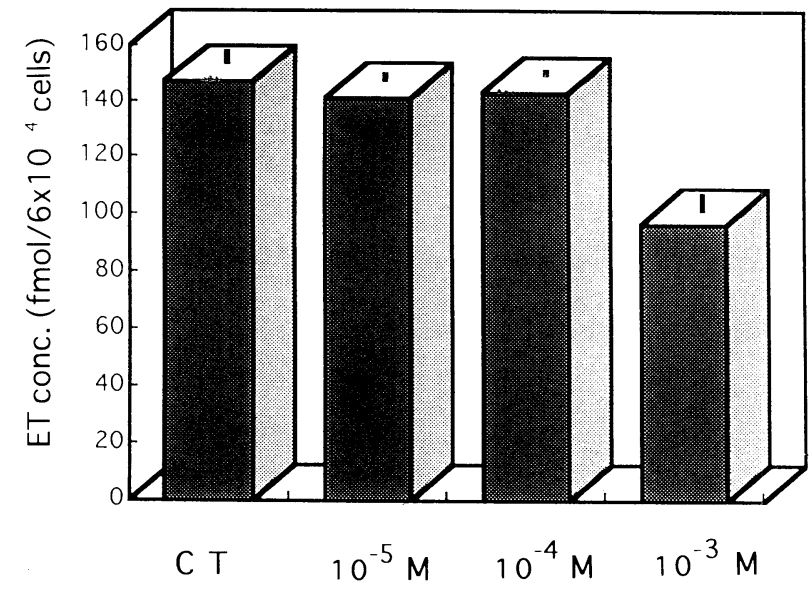

Fig. 2. Effects of 8-bromo-cyclic GMP $\left(10^{-5}, 10^{-4}\right.$ and $10^{-3} \mathrm{M}$ ) on endothelin (ET) secretion during 24 hour incubation with cultured human endothelial cells. $\mathrm{CT}=$ control. 8-bromo-cyclic GMP inhibited ET secretion at $10^{-3} \mathrm{M}(\mathrm{p}<0.01$ vs. control). Data was expressed as mean \pm SEM.

amount of ET in the control wells would be calculated at $24.8 \mathrm{fmol} /$ well. However, the actual accumulated amount of ET in the culture medium after 24 hours of incubation $(139.0 \pm 7.2 \mathrm{fmol} /$ well) was 5 times greater than this calculated value. In view of this fact, we speculated that ET secretion accelerates during the incubation period. We therefore hypothesize that ANP does not consistently inhibit ET secretion from cultured human endothelial cells, but that its inhibitory effect is evident in this acceleration of ET secretion.

Although this study did not determine which factors caused this acceleration of ET secretion from cultured endothelial cells, endothelial cells have been known to produce several vasoactive factors $(5,16-18)$ (e.g. ET, transforming growth factor $\beta$ ). Recently, ET receptors were identified in endothelial cells (19), and it was demonstrated that ET stimulates its own synthesis (20) and mitogenesis (21) of endothelial cells in cultured human endothelial cells. In addition, transforming growth factor $\beta$ was also reported to stimulate ET secretion from cultured endothelial cells $(22,23)$. We speculated that these endogenous vasoactive factors produced by cultured endothelial cells accumulate gradually in the medium during the incubation periods, and thus stimulate ET secretion in an autocrine fashion.

It was reported that ANP increases cyclic GMP concentration in endothelial cells (4). Therefore, we investigated whether 8-bromo-cyclic GMP would inhibit ET secretion from cultured human endothelial cells, and observed an inhibitory effect at the highest incubation concentration. In addition, we reported previously that nitroprusside, which is known to increase cyclic GMP concentration in endothelial cells, inhibited the stimulation of ET secretion induced by calf-serum rich conditions(24). Taken together, these findings suggest that the increase in cyclic GMP in the cells may be important for the natriuretic peptide-induced inhibitory action of ET secretion from cultured human endothelial cells.

The concentration of ANP added to the medium of the present study was more than 100 times higher than that observed in plasma under various disease conditions (2527). However, under culture conditions, the peptide in the medium may be degraded during incubation, whereas in vivo, intact ANP is supplied constantly from the heart to the local vascular tissue via blood circulation. If this ANP-induced inhibitory action of ET secretion occurs in vivo, the pathophysiological implications of this effect in the cardiovascular system must be addressed. Since increased circulating ANP levels have been reported in patients with congestive heart failure (25), hypertension (26) and chronic renal failure (27), ANP may antagonize abnormal vasoconstriction, impaired renal function and exaggerated proliferation of vascular smooth muscle cells possibly caused by ET under these pathological conditions $(10,28,29)$.

In conclusion, ANP inhibits accelerated ET secretion from cultured human endothelial cells, probably due to augmentation of intracellular cyclic GMP levels by ANPstimulated guanylate cyclase.

Acknowledgements: The authors wish to thank Mrs. Nobuko Okada for her helpful assistance with cell cultures. This work was supported by a grant from the Keiryoukai Research Foundation (No 82).

\section{References}

(1) Seymour AA, Swerdel JN, Fennell SA, Kratunis VJ, and Assad MM : Role of atrial natriuretic peptide in sodium balance in conscious spontaneously hypertensive rats. Am J Physiol, 258: F916-F926, 1990

(2) Winquist JR: Possible mechanisms underlying the vasorelaxant response to atrial natriuretic factor. Fed Proc, 45 : 2371-2375, 1986

(3) Redmond EM, Cahill PA, and Keenan AK : Atrial natriuretic factor recognizes two receptor subtypes in endothelial cells cultured from bovine pulmonary artery. FEBS Lett, 269: 157-162, 1990

(4) Leitman DC and Murad F : Comparison of binding and cyclic GMP accumulation by atrial natriuretic peptides in endothelial cells. Biochem Biophys Acta, 885 : 74-79, 1986

(5) Yanagisawa $M$, Kurihara $H$, Kimura S, Tomobe $Y$, Kobayashi M, Mitsui Y, Yazaki Y, Goto K, and Masaki T : A novel potent vasoconstrictor peptide produced by vascular endothelial cells. Nature, 332 : 411-415, 1988

(6) Komuro I, Kurihara H, Sugiyama T, Takaku F, and Yazaki $Y$ : Endothelin stimulates $\mathrm{c}-\mathrm{fos}$ and $\mathrm{c}-\mathrm{myc}$ expression and proliferation of vascular smooth muscle cells. FEBS Lett, 238 : 249-252, 1988

(7) Minkes RK and Kadowitz PJ : Influence of endothelin on systemic arterial pressure and regional blood flow in the cat. Eur J Pharmacol, 163: 163-166, 1989 
(8) Goetz KL, Wang BC, Madwed JB, Zhu JL, and Leadley RJ : Cardiovascular, renal, and endocrine responses to intravenous endothelin in conscious dogs. Am $J$ Physiol, 255 : R1064-R1068, 1988

(9) Vierhapper $\mathrm{H}$, Wagner $\mathrm{O}$, Nowotny $\mathrm{P}$, and Waldhaeusel W: Effect of endothelin-1 in man. Circulation, 81: 1415-1418, 1990

(10) Saito Y, Nakao K, Mukoyama M, and Imura H : Increased plasma endothelin level in patients with essential hypertension. N Engl J Med, 322 : 205, 1989

(11) Lerman A, Edwards BS, Hallett JW, Heublein DM, Sandberg SM, and Burmett JC Jr: Circulating and tissue endothelin immunoreactivity in advanced atherosclerosis. N Engl J Med, 525: 997-1001, 1991

(12) McMurray JJ, Ray SG, Abdullah I, Dargie HJ, and Morton $\mathrm{JJ}$ : Plasma endothelin in chronic heart failure. Circulation, 85 : 1374-1379, 1992

(13) Leppaeluoto $\mathrm{J}$ and Ruskoaho $\mathrm{H}$ : Endothelin peptides : biological activities, cellular signalling and clinical significance. Ann Med, 24 : 153-161, 1992

(14) Jaffe EA, Nachman RL, Becker CG, and Minick CR : Culture of human endothelial cells derived from umbilical veins. J Clin Invest, 52 : 2745-2756, 1973

(15) Kohno M, Yasunari K, Yokokawa K, Murakawa K, Horio $\mathrm{T}$, and Takeda $\mathrm{T}$ : Inhibition by atrial and brain natriuretic peptides of endothelin-1 secretion after stimulation with angiotensin II and thrombin of cultured human endothelial cells. J Clin Invest, 87 : 1999-2004, 1991

(16) Santilli SM, Fiegel VD, Aldridge DE, and Knighton DR: Rabbit aortic endothelial cell hypoxia induces secretion of transforming growth factor beta and auguments macrophage adhesion in vitro. Ann Vasc Surg, 5: 429438, 1991

(17) Wilson SE and Lioyd SA : Epidermal growth factor and its receptor, basic fibroblast growth factor, transforming growth factor beta-1, and interleukin-1 alpha messenger RNA production in human corneal endothelial cells. Invest Ophthalmol Vis Sci, 32 : 2747-2756, 1991

(18) Pan SH, Gharaee KM, Wolber F, and Ryan US : Stimulation of rat endothelial cell transforming growth factorbeta production by bleomycin. J Clin Invest, 87 : 148154, 1991

(19) Eguchi S, Kozuka M, Hirose S, Ito T, Hirata Y, Marumo F, and Hagiwara $H$ : Identification of $G$ protein-coupled endothelin receptors in cultured bovine endothelial cells. Biochem Biophys Res Commun, 174 : 1343-1346, 1991

(20) Saijonmaa O, Nyman T, and Fyhrquist F : Endothelin-1 stimulates its own synthesis in human endothelial cells. Biochem Biophys Res Commun, 188: 286-291, 1992

(21) Takagi Y, Fukase M, Takata S, Yoshimi H, Tokunaga O, and Fujita $T$ : Autocrine effect of endothelin on DNA synthesis in human vascular endothelial cells. Biochem Biophys Res Commun, 168: 537-543, 1990

(22) Kurihara H, Yoshizumi M, Sugiyama T, Takaku F, Yanagisawa M, Masaki T, Hamaoki $F$, Kato $H$, and Yazaki $Y$ : Transforming growth factor $-\beta$ stimulates the expression of endothelin mRNA by vascular endothelial cells. Biochem Biophys Res Commun, 159: 1435-1440, 1989

(23) Kanse MS, Takahashi K, Lam H-C, Rees A, Warren BJ, Porta M, Morinatti P, Ghatei M, and Bloom RS : Cytokine stimulated endothelin release from endothelial cells. Life Sci, 48: 1379-1384, 1991

(24) Yoshida $\mathrm{H}$ and Nakamura $\mathrm{M}$ : Inhibition by angiotensin converting enzyme inhibitors of endothelin secretion from cultured human endothelial cells. Life Sci, 50 : PL-195-PL-200, 1992

(25) Tikkanen I, Fyhrquist F, Metsarinne K, and Lendenius R : Plasma atrial natriuretic peptide in cardiac disease and during infusion in healthy volunteers. Lancet, 2 : 66-69, 1985

(26) Sangnella GA, Markandu ND, Shore A, and MacGregor GA : Raised circulating levels of atrial natriuretic peptides in essential hypertension. Lancet, 1:179-186, 1986

(27) Hasegawa K, Matsushita Y, Inoue T, Morii H, Ishibashi M, and Yamaji T : Plasma levels of atrial natriuretic peptide in patients with chronic renal failure. $\mathrm{J}$ Clin Endocrinol Metab, 63: 819-822, 1986

(28) Nakamura M, Arakawa N, Yoshida H, Funakoshi T, Chiba M, Abe Y, Makita S, Aoki H, and Hiramori K : Increased plasma endothelin concentration in patients with acute heart failure after myocardial infarction. Jpn Circ J, 57 : 371-378, 1993

(29) Shichiri M, Hirata $Y$, Ando K, Emori T, Ohta K, Kimoto S, Ogura M, Inoue A, and Marumo F: Plasma endothelin levels in hypertension and chronic renal failure. Hypertension, 15 : 493-496, 1990 